September 1988

\title{
Impact of Exchange Variables on Exit, Voice, Loyalty, and Neglect: An Integrative Model of Responses to Declining Job Satisfaction
}

Caryl Rusbult

University of North Carolina at Chapel Hill

Dan Farrell

Western Michigan University

Glen Rogers

Alverno College,grogers@pacific.edu

Arch Mainous

University of Texas at Austin

Follow this and additional works at: https://scholarlycommons.pacific.edu/provost-facarticles

Part of the Operations and Supply Chain Management Commons, Psychology Commons, and the Public Relations and Advertising Commons

\section{Recommended Citation}

https://creativecommons.org/licenses/by-nc-nd/4.0/

This Article is brought to you for free and open access by the Office of the Provost at Scholarly Commons. It has been accepted for inclusion in Office of the Provost Faculty and Staff Articles by an authorized administrator of Scholarly Commons. For more information, please contact mgibney@pacific.edu. 


\title{
IMPACT OF EXCHANGE VARIABLES ON EXIT, VOICE, LOYALTY, AND NEGLECT: AN INTEGRATIVE MODEL OF RESPONSES TO DECLINING JOB SATISFACTION
}

\author{
CARYL E. RUSBULT \\ University of North Carolina, Chapel Hill \\ DAN FARRELL \\ Western Michigan University \\ GLEN ROGERS \\ Alverno College \\ ARCH G. MAINOUS III \\ University of Texas, Austin
}

\begin{abstract}
This research offers a new theory predicting the effects of three exchange variables, job satisfaction, investment size, and quality of alternatives, on four general responses to dissatisfaction-exit, voice, loyalty, and neglect. Three studies designed to test model predictions received good support. High satisfaction and investment encouraged voice and loyalty and discouraged exit and neglect. Satisfaction and investment interacted, with variations in investment most strongly promoting voice given high satisfaction. Better alternatives encouraged exit and voice and discouraged loyalty. However, there was no link between alternatives and neglect.
\end{abstract}

One of the most important themes in the history of research on organizational behavior has been the study of employees' responses to job dissatisfaction. Concern with responses to decline in satisfaction is not misplaced. No organization can guarantee uniformly high satisfaction, and understanding the ways in which workers react to lapses in job satisfaction is central to understanding overall organizational effectiveness-job satisfaction-dissatisfaction is a critical variable linked with absenteeism, turnover, and employee dissent (Staw, 1984). Traditionally, researchers working in this domain have explored the effects of predictors such as pay or seniority on such employee responses to dissatisfaction as absenteeism, quitting, or grievance

This research was supported in part by a Dunhill Foundation grant to the first two authors from the American Society of Personnel Administrators. We are grateful to the Communication Workers of America for their willingness to participate in study two, to Linda Gellert for her assistance in carrying out study two, and to Martha Hyatt and Ramon Padilla for their help in conducting study three. We thank two anonymous reviewers for their comments on an earlier version of this manuscript. 
filing. Although that approach to the study of the consequences of declining satisfaction has been a fruitful one, shortcomings of the resulting literature are apparent.

One criticism is that investigators have not defined the dependent variables in sufficiently broad terms (Staw, 1984); as Rosse and Hulin stated, researchers tend to examine "surface variables" $(1985: 325)$ rather than behavioral patterns or syndromes representing broader theoretical constructs. For example, it is only recently that researchers have come to view job turnover and job transfer as specific examples of a more general theoretical construct (Jackofsky \& Peters, 1983). A second, related problem is the use of specific, atheoretical predictors of employee behavior (Steers \& Rhodes, 1978). The use of existing organizational characteristics and policies (e.g., retirement policies, seniority) as correlates of absence behavior illustrates this relatively concrete, atheoretical approach. Research in related fields has obtained strong predictive power by using independent and dependent variables of the same conceptual level, variables that represent abstract, unobserved constructs or response classes. An example is the use of attributional processes to explain leader emergence (Calder, 1977).

This is not to say that there are no models of response to dissatisfaction that embody a more integrative strategy. One approach to the study of responses to decline in satisfaction, often called progression theory, suggests that responses to dissatisfaction differ in intensity and that employees progress from less to more intense responses as dissatisfaction persists or intensifies (e.g., Blau, 1985; Ferris, 1985; Sheridan, 1985; Youngblood, 1984). For example, an employee might initially react to dissatisfaction with increased absence and later respond by quitting the job. Empirical tests of relationships among withdrawal behaviors have revealed significant but weak and inconsistent support for asserted relationships (Clegg, 1983; Wolpin \& Burke, 1985). A second approach has emphasized the role of performance in predicting turnover and other responses to job dissatisfaction and frustration (Jackofsky, 1984; Keller, 1984; O'Connor, Peters, Pooyan, Weekley, Frank, \& Erenkrantz, 1984; Wells \& Muchinsky, 1985). A common assumption in such models is that, given high perceived desirability of movement or low intrinsic rewards, superior performance is associated with high perceived ease of moving to another job (March \& Simon, 1958), and thus a positive relationship between performance and turnover is predicted. However, recent studies have revealed contradictory findings regarding this issue; some research has found positive associations between performance and turnover (Wells \& Muchinsky, 1985), and some has revealed negative associations (Keller, 1984; O'Connor et al., 1984). Researchers taking a third approach have proposed that absence and turnover are differentially probable as a function of length of organizational service (Hill \& Trist, 1955; Rosse \& Hulin, 1985; Rosse \& Miller, 1984). Recent work in this tradition has benefited from cognitive psychology, For example, Mowday, Porter, and Steers (1982) developed a broad cognitive model of employee turnover, including residual categories such as efforts to change a situation and "alternative modes of accommo- 
dation" (1982: 124). Though scholars taking the third approach have proposed some theories that move beyond simple unidimensional explanations and some that explore multiple responses, most of the models are fairly concrete, somewhat atheoretical, or lacking a broad set of known responses to dissatisfaction such as error rates (Petty \& Bruning, 1980), transfers (Todor \& Dalton, 1982), and grievance filing (Allen \& Keaveny, 1985; Dalton \& Todor, 1982).

This research outlined and tested a new theory intended to serve as an integrative model of responses to job dissatisfaction. The theory includes multiple predictor variables and a comprehensive typology of the range of available responses and aims at a broad, abstract level of explanation. The typology is based on Hirschman's (1970) discussion of responses to organizational decline and on Rusbult's model of responses to dissatisfaction in close relationships (Rusbult, Zembrodt, \& Gunn, 1982). The typology includes four response categories: Exit refers to leaving an organization by quitting, transferring, searching for a different job, or thinking about quitting. Voice describes actively and constructively trying to improve conditions through discussing problems with a supervisor or co-workers, taking action to solve problems, suggesting solutions, seeking help from an outside agency like a union, or whistle-blowing. Loyalty means passively but optimistically waiting for conditions to improve-giving public and private support to the organization, waiting and hoping for improvement, or practicing good citizenship. Neglect refers to passively allowing conditions to deteriorate through reduced interest or effort, chronic lateness or absences, using company time for personal business, or increased error rate.

The four categories relate to one another in a systematic fashion, as demonstrated in Farrell's (1983) multidimensional scaling study. Exit, voice,

FIGURE 1

Exit, Voice, Loyalty, and Neglect Typology of Responses to Job Dissatisfaction

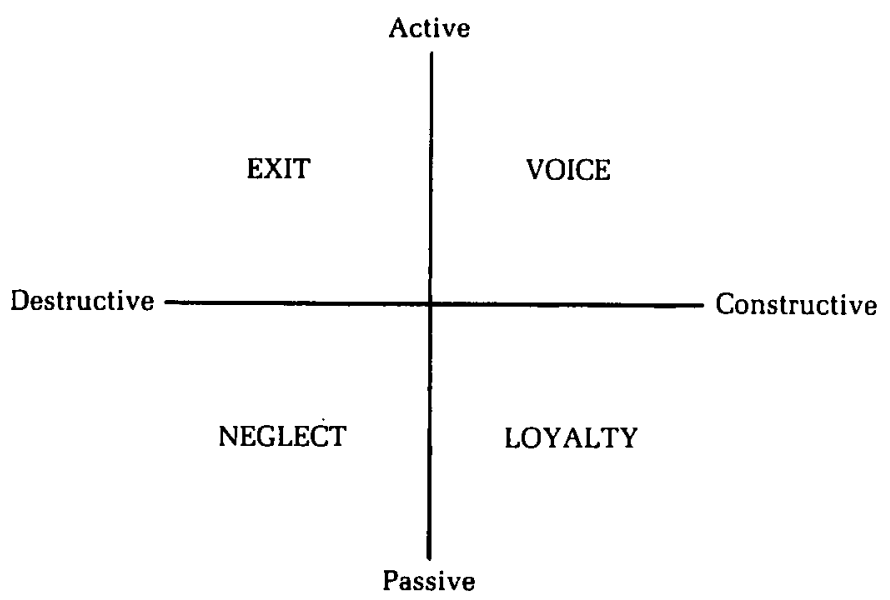


loyalty, and neglect differ along dimensions of constructiveness versus destructiveness and activity versus passivity (see Figure 1). Voice and loyalty are constructive responses in which an individual attempts to revive or maintain satisfactory employment conditions, whereas exit and neglect are more destructive. We defined the dimension of constructiveness-destructiveness in terms of impact on employee-organization relationships and immediate sources of dissatisfaction, not in terms of its broader functional value. For example, a worker's exit might be constructive for that employee or for his or her organization but destructive in that it dissolves the employee-organization link. On the second dimension, exit and voice are active mechanisms through which employees attempt to deal with dissatisfaction (Spencer, 1986), whereas loyalty and neglect are more passive and diffuse; Milburn, Schuler, and Watman suggested this contrast, stating "the individual will decide to be either passive or active vis-à-vis the antecedents of the crisis" (1983: 1165). "Passive" refers to the impact of an action on a problem and not to the character of a response itself. For example, a neglectful response, such as chronic absenteeism, involves overt action, though it is passive and destructive in regard to work problems. Finally, it should be noted that the category names are labels for a broad range of related responses. Voice includes not just vocalizing to discover solutions but also taking unilateral action to solve problems. Neglect includes very passive responses such as reduced interest as well as responses that are only moderately passive (e.g., intentionally missing work). Prior research using this typology has demonstrated that the four responses relate empirically in accordance to the hypothesized structure: behaviors within categories relate more strongly to one another than to responses in adjacent or opposing categories, and measures of each response possess both convergent and discriminant validity (Farrell, 1983; Rusbult \& Lowery, 1985). ${ }^{1}$

\section{THE IMPACT OF EXCHANGE VARIABLES ON EXIT, VOICE, LOYALTY, AND NEGLECT}

Under what circumstances are employees likely to engage in each category of response? The proposed theory extended traditional exchange theory constructs (Blau, 1964; Homans, 1961), particularly interdependence theory (Kelley \& Thibaut, 1978; Thibaut \& Kelley, 1959). ${ }^{2}$ Previous studies have

${ }^{1}$ Indeed, factor analysis of items from an instrument designed to measure exit, voice, loyalty, and neglect responses-an instrument similar to those used in the present studies-revealed excellent evidence for the proposed structure. The analysis revealed two primary factors, one with positive loadings for loyalty items and negative loadings for exit items and a second with positive loadings for voice items and negative loadings for neglect items (Farrell \& Rusbult, 1986).

2 The assumptions underlying the model mirror those of interdependence theory. We assumed that employees react in a sensible and reasonable manner to work situations, given their dispositions and perceptions of situational contingencies. In reacting to a given situation, individuals consider both immediate and long-term consequences for themselves and for others with whom they are interdependent. Such responses are often based on deliberate, thoughtful decisions, though habitual response tendencies may develop in reaction to familiar situations. 
used the critical predictors in the model to account for employee turnover (Farrell \& Rusbult, 1981; Rusbult \& Farrell, 1983). We suggest that three primary variables should affect the likelihood that an employee will engage in each response-level of overall job satisfaction, or satisfaction prior to a problem; magnitude of investment in a job; and quality of job alternatives. We have defined the three predictors broadly and abstractly, and thus they match the conceptual level of the exit, voice, loyalty, and neglect model.

First, in comparison to employees who were satisfied with a job before the emergence of problems, employees with lower prior satisfaction should be more likely to engage in destructive responses and less likely to engage in constructive responses. As has been well documented elsewhere, the components of job satisfaction include feelings regarding supervision, pay, and co-worker relations ( Hulin \& Smith, 1965; Locke, 1969). To the degree that overall satisfaction is great, employees should evidence a strong tendency to respond to specific work problems with voice or loyalty and should display a weak tendency to react with exit or neglect. ${ }^{3}$ Employees who have been generally satisfied with their jobs should feel strongly motivated to restore good working conditions and may also feel optimistic about the possibilities for improvement. Although previous research has not directly examined level of prior satisfaction, there is some good indirect support for these assertions: Low job satisfaction has been shown to be associated with strong tendencies toward exit behaviors such as quitting (Cotton \& Tuttle, 1986; Dalessio, Silverman, \& Schuck, 1986; Steel \& Ovalle, 1984), transferring (Campion \& Mitchell, 1986; Todor, 1980), and intending to quit (Hom, Griffeth, \& Sellaro, 1984; Mowday, Koberg, \& McArthur, 1984) and has also been associated with tendencies toward neglectful behaviors such as lateness (Adler \& Golan, 1981; Farrell \& Robb, 1980), increased error rate (Petty \& Bruning, 1980), and absence (Gaudet, 1963; Muchinsky, 1977). High job satisfaction appears to promote voice behaviors such as grievance filing (Allen \& Keaveny, 1985; Dalton \& Todor, 1982; Price, Dewire, Nowack, Schenkel, \& Ronan, 1976) and making job suggestions (VanZelst \& Kerr, 1953) and acts of loyalty such as good citizenship behavior (Bateman \& Organ, 1983; Smith, Organ, \& Near, 1983) and job commitment (Aranya, Kushnir, \& Valency, 1986; Ferris \& Aranya, 1983). Thus,

Hypothesis 1: Employees with high levels of overall job satisfaction and high prior satisfaction should be more likely to engage in voice and loyalty and less likely to

\footnotetext{
${ }^{3}$ It is useful to think of prior satisfaction, or overall satisfaction, as the ground against which the figure of a current dissatisfying incident is evaluated. In the final analysis, it is probably the relationship between level of overall satisfaction and level of current dissatisfaction that directly influences response mode. Thus, a more precise definition of current dissatisfaction and a more precise prediction of response tendencies may ultimately result from a mathematical combination of information about variables such as prior/general satisfaction, probability of future satisfaction, severity of a specific work problem, and importance of a specific work problem.
} 
engage in exit and neglect than employees with low overall job satisfaction.

Second, the constructiveness of employees' responses to dissatisfaction should be positively related to their investment in their jobs. By investment, we mean resources an employee has put into a job that have become intrinsic to that position, such as years on the job, nonportable training, familiarity with the organization and supervisor, and nonvested retirement funds, and resources that were originally extraneous but have become connected to the job, such as convenient housing and travel arrangements and friends at work (Becker, 1960; Ritzer \& Trice, 1969; Rubin \& Brockner, 1975). Employees who have great investment in their jobs have much to lose by abandoning them and should be more likely to engage in voice or loyalty than those with low investment. With low investment, an employee has little to lose if the job were to end, so exit and neglect responses should become more probable. Indeed, previous research has linked voice behaviors such as making job suggestions and grievance filing with investments such as seniority (VanZelst \& Kerr, 1953) and prior promotions (Price et al., 1976). Psychological and material investment has been shown to promote loyalty responses such as commitment, positive work attitudes, and good citizenship behavior (Arkes \& Blumer, 1985; Buchanan, 1974; Meyer \& Allen, 1984). Quitting and intent to quit appear to be inhibited by relatively greater length of service (Ferris \& Aranya, 1983; Rusbult \& Farrell, 1983; Werbel \& Gould, 1984; Youngblood, Mobley, \& Meglino, 1983), identification with a job (Koch \& Steers, 1978), and training (Guzzo, Jette, \& Katzell, 1985; Wanous, Stumpf, \& Bedrosian, 1979). Similarly, previous research has shown neglectful behaviors like absence, lateness, and lack of effort to be inversely related to investments such as cross-training, work-connected recreational programs, and home ownership (Pascale, 1978; Watson, 1981). Thus,

Hypothesis 2: Employees with high investment in a job should be more likely to engage in voice and loyalty and less likely to engage in exit and neglect than employees with low investment.

Third, to the degree that employees have high-quality alternatives to their current job, they should be likely to engage in active responses. Good alternatives, such as attractive job opportunities, the possibility of early retirement, or the acceptable option of not working, create in an individual the motivation to do something (shape up or ship out) and provide a source of power for bringing about change because the employee has acceptable options if the job declines further or ends. In the absence of good alternatives, the options are to wait quietly for conditions to improve (remain loyal) or to passively allow conditions to worsen (engage in neglect). The findings of research on the effects of alternatives such as employment opportunities, high personal esteem, labor supply, and external support have been consistent with those predictions. Good alternatives promote exit behaviors such as quitting and intent to quit (Dreher \& Dougherty, 1980; Farrell \& Rusbult, 
1981; Mowday et al., 1984; Price \& Mueller, 1981; Schneider, 1976; Stumpf \& Hartman, 1984) and voice behaviors such as whistle-blowing (Miceli \& Near, 1984), grievance filing (Fleishman \& Harris, 1962; Muchinsky \& Maassarani, 1980), and constructive social movements (Lammers, 1969; Zald \& Berger, 1978). Employees with poor alternatives evidence high levels of loyal behaviors like job commitment (McLaughlin \& Butler, 1974; Pfeffer \& Lawler, 1980) and of neglectful responses like absenteeism and slow-down behaviors (Behrend, 1953; Crowther, 1957; Larson \& Fukami, 1985; Owens, 1966; Watson, 1981; Youngblood, 1984). Thus,

Hypothesis 3: Employees with high-quality alternatives should be more likely to engage in exit and voice and less likely to engage in loyalty and neglect than employees with poor-quality alternatives.

\section{TESTS OF THE MODEL}

We designed three studies to provide direct empirical tests of this model. Study one, a simulation experiment, provided preliminary information regarding the causal impact of the model's variables on responses to dissatisfaction and allowed for the study of variables, such as intense dissatisfaction, that are difficult to manipulate ethically and powerfully in a laboratory experiment. Study two, a large-scale cross-sectional field survey, extended external validity in two ways. First, it explored the effects of generalized job satisfaction, investment size, and quality of alternatives on generalized tendencies toward exit, voice, loyalty, and neglect. Second, it tested the model's predictions among actual employees. Study three, a laboratory experiment, complemented studies one and two, focusing on the causal impact of model variables in an experimental work setting, by examining temporal changes in response tendencies over an extended period of declining satisfaction and by using additional-and more behavioral-measures of exit, voice, loyalty, and neglect.

The three studies complemented one another to maximize both construct and external validity (Cook \& Campbell, 1979). Employing multiple methodologies and multiple measurement methods enhanced construct validity. Exploring response tendencies for multiple populations (simulated and real employees) in multiple settings enhanced external validity.

\section{STUDY ONE}

\section{Methods}

Subjects. Sixty-four men and 64 women participated to fulfill the research experience requirements for introductory psychology at the University of Kentucky during the 1984-85 academic year. We randomly assigned 8 men and 8 women to each of eight conditions. No data were excluded.

Procedures. Approximately 20 students reported to each laboratory session, where the experimenter (one of the authors) delivered instructions. 
Each subject read an essay describing a hypothetical situation in which the protagonist was faced with declining working conditions (see Appendix A). The hypothetical employee's supervisor had begun to give arbitrary and inconsistent instructions, and the employee felt that those instructions were neither appropriate nor helpful.

Level of prior job satisfaction was manipulated through variations in descriptions of the employee's job. Employees worked for a mediocre or for a good company that provided a decent or a high salary for work that was described as moderately or as really enjoyable. Investment size was manipulated through variations in job tenure. Employees had worked for the company for a short or for a long period of time-two months or two years. Quality of alternatives was manipulated through variations in descriptions of an alternative job offer. Employees had offers that were not very or very attractive, with poor or good pay and no challenge or high challenge (see Appendix A). Participants were asked to place themselves mentally in the situation described and to complete a questionnaire indicating how they would react. The questionnaire included two manipulation checks for each independent variable and a 17-item scale that measured tendencies toward each response to dissatisfaction. There were four items each to measure exit, voice, and loyalty and five to measure neglect (see Appendix A).

\section{Results}

Reliability of measures. Reliability coefficients were calculated for the measures designed to assess tendencies toward exit, voice, loyalty, and neglect as well as for the manipulation checks for each independent variable. Table 1 presents alphas for each set. The coefficient for the voice items was lower than desired, which suggests that this category may be more heterogeneous than the others. ${ }^{4}$ In addition, we assessed the discriminant validity of our measures by calculating the average correlation between the items in each set and those in every other set. For example, the four exit items were correlated with the four voice items, producing a matrix of 16 correlation coefficients, which we averaged. As expected, given the structure of the typology, these correlations were negligible or weak. The average $r$ was .00 ; the range was from -.24 to .18 . The average $r$ for opposing categories was -.17 , the average $r$ for adjacent categories was .06 , and the average $r$ for items within categories was .42 . We judged the items designed to measure

\footnotetext{
${ }^{4}$ That some categories may be more heterogeneous should not be surprising. For example, the strength of the reliability coefficient for the exit category suggests that exit may be a largely homogeneous category of response. It is likely that employees who say that they intend to quit will also say that they have explored alternative jobs and have thought about quitting. In contrast, the coefficient for the voice category is lower. Those who voice by discussing problems with their supervisor will not necessarily engage in other forms of voice. Thus, variability in size of reliability coefficients may reflect real differences in category complexity. Such differences do not undermine the usefulness of the proposed typology. Its usefulness lies in its ability to identify categories wherein responses within a given category bear more conceptual and empirical similarity to one another than to responses in other categories.
} 
each set to be acceptably reliable and distinct from those designed to measure other response categories, so we formed a single averaged measure of each construct.

Manipulation checks. The manipulation checks were subjected to a threefactor analysis of variance. Subjects in the low-prior-satisfaction condition reported lower satisfaction with their jobs than did those in the high-priorsatisfaction condition $\left(x=4.31\right.$ and 8.27 , respectively; $F_{1,120}=497.58, p<$ .001). ${ }^{5}$ Low-investment participants reported lower investment size than did their high-investment counterparts $\left(\bar{x}=2.55\right.$ and 6.48 , respectively; $F_{1,120}=$ $264.49, p<.001$ ). And participants in the poor-alternatives condition described their alternatives more negatively than did those in the goodalternatives condition $\left(\bar{x}=1.86\right.$ and 7.86 , respectively; $F_{1,120}=1,455.92, p<$ $.001)$. We examined interaction terms to assess the stability of our manipulations. No sizable interaction effects were observed: the next largest $F$ value was 7.68, which is small in comparison to those listed above.

Testing model predictions. To test our predictions, a three-factor multivariate analysis of variance was performed on the exit, voice, loyalty, and neglect measures. Table 2 presents both multivariate and univariate $F$ s for each main effect. Consistent with predictions, the multivariate effect of prior satisfaction was significant, with high satisfaction producing strong tendencies toward voice and loyalty and weak tendencies toward exit and neglect. The multivariate effect of the investment-size manipulation was marginally significant: high investment size produced low levels of exit and high levels of loyalty. The investment manipulation did not significantly affect voice or neglect, however. The multivariate effect of the manipulation of quality of alternatives was significant, with good alternatives encouraging high exit and voice and discouraging loyalty. The quality-of-alternatives manipulation did not significantly affect neglect responses.

TABLE 1

Reliability Coefficients for All Model Variables, Studies One, Two, and Three

\begin{tabular}{lccccccc}
\hline & $\begin{array}{c}\text { Job } \\
\text { Satisfaction }\end{array}$ & $\begin{array}{c}\text { Investment } \\
\text { Size }\end{array}$ & $\begin{array}{c}\text { Quality of } \\
\text { Alternatives }\end{array}$ & Exit & Voice & Loyalty & Neglect \\
\hline Study one & .97 & .81 & .98 & .89 & .45 & .75 & .79 \\
Study two & .84 & .62 & .78 & .76 & .57 & .56 & .69 \\
Study three & .77 & .85 & .58 & .97 & .77 & .70 & .82 \\
\hline
\end{tabular}

${ }^{a}$ Table values are the alphas for the set of items associated with each construct for each study. For study two, the job-satisfaction, investment-size, and quality-of-alternatives measures are the predictor variables; for studies one and three they are the manipulation checks.

\footnotetext{
${ }^{5}$ Further analyses of the manipulation-check data revealed that the effects discussed herein were robust, holding not only for the averaged manipulation checks but also for the individual manipulation check items that were combined to form the averaged measure.
} 
TABLE 2

Results of MANOVA, Study One ${ }^{a}$

\begin{tabular}{lccccc}
\hline \multicolumn{1}{c}{ Variables $^{\mathrm{b}}$} & Exit & Voice & Loyalty & Neglect & Multivariate $F^{\mathbf{c}}$ \\
\hline High job satisfaction & 3.15 & 6.70 & 5.23 & 2.64 & \\
Low job satisfaction & 4.94 & 6.25 & 3.53 & 3.18 & \\
F & $55.58^{\star \star}$ & $3.97^{\star}$ & $47.31^{\star \star}$ & $3.83^{\star \star}$ & $22.48^{\star \star}$ \\
High investment size & 3.80 & 6.60 & 4.67 & 2.81 & \\
Low investment size & 4.29 & 6.36 & 4.09 & 3.01 & \\
F & $4.17^{\star}$ & 1.12 & $5.65^{\star}$ & 0.55 & $2.27 \dagger$ \\
High-quality alternatives & 5.65 & 6.75 & 3.90 & 2.77 & \\
Low-quality alternatives & 2.44 & 6.21 & 4.86 & 3.05 & \\
$F$ & $177.46^{\star \star}$ & $5.64^{\star}$ & $15.20^{\star \star}$ & 1.04 & $63.75^{\star \star}$ \\
\hline
\end{tabular}

${ }^{a}$ Values are the mean level of each response, each of which had a possible range from 1 to 9 .

b The $F$ rows list the univariate effect of each independent variable on each dependent variable.

c The multivariate $F$ column lists the multivariate effect of each independent variable on the four responses.

$$
\begin{aligned}
t p & <.10 \\
{ }^{*} p & <.05 \\
{ }^{\star} p & <.01
\end{aligned}
$$

To explore the boundaries of the simple additive model presented in the introduction, we also examined interaction terms. There were two significant two-factor interactions. The interaction of satisfaction and investment was significant for the voice measure; high investment encouraged strong voice only under conditions of high satisfaction. The second interaction was an intensification effect. Good alternatives encouraged exit given either low or high satisfaction, but this effect was strongest under conditions of low prior satisfaction.

To assess the generalizability of these findings for men and women, we performed a four-factor multivariate analysis of variance. Only one effect involving gender was significant: gender, prior satisfaction, and investment interacted in affecting voice. Women voiced at high levels given high satisfaction and high investment or low satisfaction and low investment. Men voiced as predicted-high investment encouraged strong voice with either low or high satisfaction.

\section{STUDY TWO}

\section{Methods}

Respondents. The respondents were employees of a large communications utility company. A randomly selected third of the membership of 11 locals of the representing union $(n=864)$ were mailed questionnaires, cover letters, and stamped return envelopes in the spring of 1983. We mailed two sets of follow-up materials, following Dillman's (1978) methods. The overall response rate was 55 percent, with 473 employees responding, 54 percent of 
whom were men. ${ }^{6}$ The typical respondent was 40.9 years of age, had 12.5 years of schooling, and earned $\$ 23,200$ per year.

Questionnaire. The questionnaire obtained measures of all model predictors and criteria as well as demographic information. For each independent variable-job satisfaction, investment size, and quality of alternatives-we obtained both concrete and global measures. The concrete measures taught respondents the meaning of the global items (Farrell \& Rusbult, 1981; Rusbult \& Farrell, 1983). For example, it might be difficult to answer the question, "Are there things uniquely associated with this job that you would lose if you were to leave?" without a few concrete examples of investments that might be lost such as nonvested retirement funds and specific job training. Most of the concrete items had 3-point Likert-type scales, and all the global items had 5-point Likert scales. The exit, voice, loyalty, and neglect items were similar to those employed in study one, altered to measure generalized response tendencies rather than responses to a particular dissatisfying incident and to be appropriate for actual employees (see Appendix B).

\section{Results}

Reliability of measures. Table 1 presents reliability coefficients for each variable. As in study one, we assessed the discriminant validity of the items by calculating correlations between items from each set and those from every other set. Again, these correlations were low (average $r=-.01$, range $=-.15$ to .16), with an average correlation of -.11 for items in opposing categories and an average of .04 for items in adjacent categories (average $r$ for items within categories $=.33$ ). Since our measures appeared to be acceptably reliable within categories and discrete across categories, we formed a single averaged measure of each construct.

Validity of independent variables. Both concrete and global measures of the three independent variables were obtained. We used multiple regression analysis to assess the relationship between the several concrete measures of each construct and their global counterparts. We found evidence for the validity of our measures: concrete measures were significantly correlated with global measures for job satisfaction (adjusted $R^{2}=.499$ ), investment size (adjusted $R^{2}=.349$ ), and quality of alternatives (adjusted $R^{2}=.490$ ). Thus, our predictor variables appeared to be valid measures of the constructs they were intended to assess.

Testing model predictions. To assess the effects of all predictors on each response, we performed four multiple regression analyses with simultaneous inclusion of predictors. Table 3 presents means, standard deviations, and zero-order correlations, and Table 4 presents a summary of the results of the multiple regression analyses. Collectively, satisfaction, investment, and alternatives significantly predicted each of the four responses. Higher job satisfaction was associated with higher loyalty and lower exit and neglect. Higher

\footnotetext{
- Thus, our sample resembled national labor force averages in education and proportion of men; members were slightly older and earned slightly higher salaries than the average.
} 
investment size was associated with higher tendencies toward voice and lower tendencies toward exit and neglect. And good alternatives encouraged the exit and voice responses. No other regression coefficients were significant, though the zero-order correlations were significant for the investment-loyalty $(r=.15)$ and alternatives-loyalty $(r=-.12)$ relationships.

To determine whether the interactions observed in study one emerged in study two, we performed a median split on the satisfaction measure and calculated separate investment-voice correlations for the low- and highsatisfaction groups. Consistent with study one's results, those analyses revealed that the investment-voice relationship was greater for the highsatisfaction group than for the low-satisfaction group, but this difference was not statistically significant $(r=.12$ and .07 , respectively; $z=1.11$ ) (Cohen \& Cohen, 1975). Also consistent with study one, the investment-voice correlation was significantly greater for men than for women $(r=.21$ and -.09 , respectively; $z=6.57$ ). In study one we also found that the impact of quality of alternatives on exit was strongest given low job satisfaction. No such intensification effect emerged in study two. Quality of alternatives was as

TABLE 3

Means, Standard Deviations, and Zero-Order Correlations, Study Two

\begin{tabular}{lcccccccc}
\hline \multicolumn{1}{c}{ Variables } & Means & s.d. & 1 & 2 & 3 & 4 & 5 & 6 \\
\hline 1. Exit & 1.93 & 1.28 & & & & & & \\
2. Voice & 3.56 & 1.26 & $.21^{\star \star}$ & & & & & \\
3. Loyalty & 3.31 & 1.30 & $-.33^{\star \star}$ & -.03 & & & & \\
4. Neglect & 1.63 & 0.98 & $.31^{\star \star}$ & .01 & $-.18^{\star \star}$ & & & \\
5. Job satisfaction & 3.51 & 1.43 & $-.52^{\star \star}$ & -.09 & $.34^{\star \star}$ & $-.13^{\star \star}$ & & \\
6. Investment size & 2.34 & 1.23 & $-.29^{\star \star}$ & .08 & $.15^{\star *}$ & $-.14^{\star \star}$ & $.29^{\star *}$ & \\
7. Quality of alternatives & 3.73 & 1.12 & $.36^{\star \star}$ & $.25^{\star \star}$ & $-.12^{\star \star}$ & .00 & $-.22^{\star \star}$ & $-.20^{\star *}$ \\
\hline
\end{tabular}

$\star * p<.01$

TABLE 4

Results of Multiple Regression Analyses, Study Two

\begin{tabular}{lcccc}
\hline & Exit & Voice & Loyalty & Neglect \\
\hline Job satisfaction & & & \\
Investment size & $-.432^{\star \star}$ & -.071 & $.331^{\star \star}$ & $-.112^{\star}$ \\
Quality of alternatives & $-.117^{\star \star}$ & $.164^{\star \star}$ & .054 & $-.121^{\star}$ \\
Multiple $R$ & $.228^{\star \star}$ & $.276^{\star \star}$ & -.041 & -.052 \\
Adjusted $R^{2}$ & .582 & .297 & .358 & .176 \\
Multivariate $F_{3,462}$ & .335 & .082 & .123 & .025 \\
\hline
\end{tabular}

a Values for job satisfaction, investment size, and quality of alternatives are regression coefficients.

\footnotetext{
${ }^{*} p<.05$

${ }^{\star *} p<.01$
} 
strongly correlated with exit among low-satisfaction respondents as among high-satisfaction respondents $(r=.31$ and .32 , respectively; $z=0.00$ ).

To explore possible gender effects, we calculated correlations among all predictors and criteria separately for the two genders. The only notable difference was for the investment-voice relationship. Consistent with the results of study one, high investment size consistently promoted voice among men but not among women $(r=.16$ and .00 , respectively; $z=3.49$ ).

\section{STUDY THREE}

\section{Methods}

Subjects. Forty men and 40 women participated to fulfill the research experience requirements for introductory psychology at the University of Kentucky during the 1984-85 academic year. We randomly assigned each of six students recruited for each session to one of eight conditions; ultimately, there were ten subjects per condition. Students received $\$ 5.00$ for their participation in the two-hour experiment.

Procedures. The study was a simulation of a newspaper newsroom. The experimenter described a variety of available work tasks and discussed the average pay per session for each task. She then allegedly randomly assigned initial tasks to subjects; however, the task-decoding reports written in "reporters' speed writing"-did not actually vary. The experimenter told the subjects that after three work sessions they would have the option of switching to a second task, which was in fact always transcribing telex messages. She also informed them that their supervisor, "an M.B.A. student," was in the next room behind a one-way mirror. Subjects were given ten minutes to read training materials to "prepare them for their work." At the end of the training session the supervisor entered the room, distributed work materials, and left. He returned after five minutes, collected the work, and retired to his office to prepare written evaluations. When he returned, he gave all subjects a written evaluation of their work during the first session and distributed a set of materials for the second session. This procedure was followed for a total of three work sessions.

Independent variable manipulations. Four variables were manipulated: Prior satisfaction was varied by manipulating anticipated pay for the assigned task; on the average, expected pay was $\$ 4.30$ for the high-satisfaction condition and $\$ 2.85$ for the low-satisfaction condition. Quality of alternatives was manipulated by varying anticipated pay for the new task available after three work sessions; on the average, expected pay was $\$ 4.35$ for the good-alternatives condition and $\$ 2.90$ for the poor-alternatives condition. Investment size was varied through the training subjects received. They received specific work training in how to decode reporters' speed writing in the high-investment condition and received general work training that described a variety of newsroom tasks in the low-investment condition. Over the course of three sessions, the task became increasingly difficult and the 
supervisor's evaluations became increasingly negative. The evaluation feedback form included five-option evaluations (poor, passing, adequate, good, superior) along seven dimensions of performance (e.g., completeness of work, readability). Over the three sessions, the job became more difficult and the evaluator's feedback declined from an average rating of adequate-to-good in session 1 to an average rating of passing-to-adequate in session 2 to an average rating of passing in session 3. The supervisor's feedback included written comments, which also became more negative: "This was about what I expected for the first work period" for session 1, "I'm not really happy with this one. Work harder!" for session 2, and "This was pretty poor, and the story wasn't that hard. Are you awake!" for session 3.

Manipulation checks and dependent variables. At the end of each work session subjects completed questionnaires that measured self-reported tendencies toward each response and assessed the effectiveness of each manipulation. On the measures of response to job dissatisfaction, subjects were asked to assume that the previous session represented experiences during a one-month period ${ }^{7}$ and to report on likelihood of engaging in each response. All measures were 7-point scales (see Appendix C). At the end of session 3, behavioral measures were obtained. Subjects selected one of four memos to send the supervisor. The memos read as follows:

Exit: I have considered the benefits and drawbacks of my alternative and the task l've been doing. I would like to transfer to my alternative job.

Voice: I'd like to keep working on this task, but you should make some changes. I have some questions and suggestions regarding our feedback and evaluation system. Can I talk to you about my ideas?

Loyalty: All things considered, I believe the best thing for me is to stick with my current task. I would say that a job like this is better than most.

Neglect: I've lost some enthusiasm for my work, but I'll continue with my assigned job. If you looked around you'd probably see that workers here are becoming unhappy and are losing their motivation to work hard.

\section{Results}

Reliability of measures. Table 1 presents reliability coefficients for the manipulation checks and response-to-dissatisfaction items. As in studies one and two, we evaluated the discriminant validity of our items by calculating correlations between all items within each set and the items that composed every other set. Those statistics provided good evidence for distinc-

\footnotetext{
${ }^{7}$ Participants were asked to adopt this time perspective so that all available responses to job dissatisfaction would in fact be viable options. For example, it makes sense to speak of tendencies toward increased absenteeism or lateness when speaking of a month on a real job, whereas such responses are not logical possibilities within the context of a two-hour laboratory experiment.
} 
tiveness across sets (average $r=.00$; range $=-.28-.25$ ); the average correlation between items from opposing categories was -.12 , and the average correlation between items from adjacent categories was .06 (average $r$ within categories $=.50$ ). Since our measures appeared to be acceptably reliable within categories and distinct across categories, we calculated a single averaged measure of each construct.

Manipulation checks. Four-factor analyses of variance with three between-subjects factors (satisfaction, investments, alternatives) and one within-subjects factor (session 1,2, or 3) were performed on the manipulation checks to assess the effectiveness of each experimental manipulation. In comparison to subjects in the low-prior-satisfaction condition, those in the high-prior-satisfaction condition reported significantly greater satisfaction with their assigned task $\left(x=2.54\right.$ and 4.68 , respectively; $F_{1,209}=207.28$, $p<.001)$. Subjects in the low-investment condition reported that they had significantly less invested in their assigned task than did those in the highinvestment condition $\left(\bar{x}=3.71\right.$ and 5.58 , respectively; $F_{1,209}=237.63, p<$ .001). Subjects in the low-quality-of-alternatives condition viewed their alternative task as less attractive than did those in the high-alternatives condition $\left(\bar{x}=2.75\right.$ and 5.19 , respectively; $\left.F_{1,209}=226.58, p<.001\right)$. In addition, over the course of the three work sessions there was a marginally significant decline in satisfaction with working conditions $(\bar{x}=3.84,4.15$, and 4.23 , respectively; $F_{1,209}=2.68, p<.071$ ). Thus, participants appear to have experienced our manipulations as intended; each of the manipulations created the intended conditions. $^{8}$

Testing model predictions: Self-report measures. A four-factor analysis of variance on the self-report measures revealed significant multivariate effects of all four independent variables (see Table 5). Consistent with predictions, high job satisfaction promoted voice and loyalty and inhibited exit. The manipulation of investment size significantly affected only the neglect measure. High-quality alternatives promoted exit and voice but did not significantly affect the passive loyalty or neglect responses. And over time, declining working conditions produced increases in exit, voice, and neglect, and reductions in loyal behavior.

As did studies one and two, study three revealed a significant interaction between job satisfaction and investment size, with high investment promoting voice more strongly under conditions of high satisfaction. No other interactions were statistically significant in the four-factor analyses. A five-factor

\footnotetext{
${ }^{8}$ Further analyses of the manipulation-check data revealed that the effects discussed herein were robust, holding not only for the averaged manipulation checks but also for the individual manipulation check items that were combined to form the averaged measure. The effect on the manipulation checks of the independent variable, decline in satisfaction, may have been only marginally significant because this set of items was somewhat more heterogeneous than were the other sets of manipulation check items (see Appendix C). Indeed, the reliability coefficient for this set of items was only .20. However, this independent variable significantly influenced all four measures of response to dissatisfaction, suggesting that the manipulation was probably appropriately powerful.
} 
TABLE 5

Results of MANOVA, Study Three ${ }^{a}$

\begin{tabular}{lcllll}
\hline \multicolumn{1}{c}{ Variables } & Exit & Voice & Loyalty & Neglect & Overallb \\
\hline Self-report measures & & & & & \\
High job satisfaction & 2.96 & 4.10 & 4.12 & 2.46 & \\
Low job satisfaction & 4.08 & 3.78 & 3.83 & 2.39 & \\
F & $19.59^{\star \star}$ & $4.25^{\star}$ & $5.68^{\star}$ & 0.24 & $6.26^{\star \star}$ \\
High investment size & 3.68 & 3.91 & 3.91 & 2.27 & \\
Low investment size & 3.41 & 3.98 & 4.04 & 2.58 & \\
F & 0.75 & 0.38 & 2.05 & $4.87^{\star}$ & $2.35^{\star}$ \\
High-quality alternatives & 4.18 & 4.08 & 3.96 & 2.43 & \\
Low-quality alternatives & 2.86 & 3.81 & 3.99 & 2.42 & \\
F & $29.85^{\star \star}$ & $3.07^{\star \star}$ & 0.05 & 0.00 & $7.54^{\star \star}$ \\
Low decline in satisfaction & 3.08 & 3.58 & 4.35 & 2.10 & \\
Moderate decline in satisfaction & 3.58 & 3.90 & 3.95 & 2.47 & \\
High decline in satisfaction & 3.91 & 4.35 & 3.62 & 2.72 & \\
F & $4.90^{\star *}$ & $8.90^{\star \star}$ & $8.59^{\star \star}$ & $6.54^{\star \star}$ & $3.94^{\star \star}$ \\
Behavioral measures & & & & & \\
High job satisfaction & 9 & 14 & 8 & 9 & \\
Low job satisfaction & 15 & 9 & 5 & 11 & $1.83^{\star}$ \\
High investment size & 11 & 13 & 9 & 7 & \\
Low investment size & 13 & 10 & 4 & 13 & $1.83^{\star}$ \\
High-quality alternatives & 16 & 11 & 6 & 7 & \\
Low-quality alternatives & 8 & 12 & 7 & 13 & $1.62^{\star}$ \\
\hline
\end{tabular}

a For the self-report measures, values are mean levels of each response, ranges 1-7. For the behavioral measures, values are the number of participants who selected each response.

"For the self-report measures, the column labeled "overall" lists the multivariate effect of each independent variable; for the behavioral measures, lists z's for the tests of differences in proportions (for the satisfaction and investment rows, the $z$ for the constructiveness-destructiveness contrast; for the alternatives row, the $\mathrm{z}$ for the activity-passivity contrast).

${ }^{\star} p<.05$

$\star \star p<.01$

analysis of variance revealed only one significant effect involving gender: the main effect of gender on neglect was significant, with men engaging in higher levels of neglect than women.

Testing model predictions: Behavioral measures. At the end of three work sessions, subjects selected one of four memos to send to the supervisor. Table 5 displays the number who chose each response. We used tests of differences between proportions to assess the effects of each manipulation on response tendencies. Since subjects could elect to engage in any one of four responses, the absolute number engaging in each response was low and tests of differences in proportions for each individual response were relatively weak. Therefore, in each test we combined two conceptually related categories of response. For each independent variable, we examined differences in tendencies toward constructive responses (voice plus loyalty) rather than destructive responses (exit plus neglect) and toward active responses (exit plus voice) rather than passive responses (loyalty plus neglect). As 
predicted, in comparison to participants in the low-satisfaction condition, those in the high-satisfaction condition were more likely to engage in constructive responses and less likely to engage in destructive responses. Subjects in the low-investment condition were more likely to react constructively and less likely to react destructively. The effect for exit was weak. Compared to subjects with low-quality alternatives, those with good alternatives were more likely to react actively and less likely to react passively; those effects were strongest for exit and neglect. As expected, the quality-ofalternatives manipulation did not affect behaviors along the constructivenessdestructiveness dimension, and neither the satisfaction nor investment manipulation affected behaviors along the activity-passivity dimension. There were too few observations per cell to explore interactions or gender effects.

\section{DISCUSSION}

Meta-analytic techniques were employed to combine information and develop summary probability estimates across the three studies (Rosenthal, 1983). Table 6 presents the results of those analyses. In calculating overall $z$-scores we used the following information: For study one we employed univariate $F$ s for each main effect. For study two we employed univariate Fs for each regression coefficient. For study three we employed univariate Fs for each main effect for the self-report measures and $z$-scores for individual contrasts for the behavioral measures, weighting each resultant $z$ by .5. Thus, each study was equally weighted in the final combined statistic for each effect.

The results of the three studies provide very good support for the proposed theory. Consistent with the first hypothesis, high job satisfaction fairly consistently promoted the constructive voice and loyalty responses and inhibited the destructive exit and neglect responses. And consistent with the second hypothesis, high levels of investment fairly consistently encouraged voice and loyalty responses and inhibited exit and neglect. Finally, consistent with the third hypothesis, the possession of high-quality alternatives

TABLE 6

Meta-Analysis of Results: Studies One, Two, and Three ${ }^{a}$

\begin{tabular}{lllll}
\hline & Exit & Voice & Loyalty & Neglect \\
\hline Impact of job satisfaction & $5.97^{\star \star \star}$ & $1.77^{\star}$ & $5.07^{\star \star \star}$ & $2.49^{\star \star}$ \\
Impact of investment size & $2.52^{\star \star}$ & $2.26^{\star \star}$ & $1.78^{\star}$ & $2.91^{\star \star}$ \\
Impact of quality of alternatives & $6.05^{\star \star \star}$ & $3.74^{\star \star *}$ & $2.25^{\star \star}$ & 1.50 \\
\hline
\end{tabular}

a Values are $z$-scores from a meta-analysis. For each study, z's were: study one, univariate $F$ for each main effect; study two, univariate $F$ for each regression coefficient; study three, I(univariate $F$ for each main effect, self-report measures) + ( $z$ for individual contrasts, behavioral measures)]/2.

" $p<.05$, one-tailed test.

${ }^{\star *} p<.01$, one-tailed test.

$\star * * p<.001$, one-tailed test. 
encouraged high levels of the active exit and voice responses and inhibited loyalty, although this effect was somewhat inconsistently observed. However, there was very little evidence of a link between quality of alternatives and tendencies toward neglect.

Although the simple effects of satisfaction and investment on voice were weak, in all three studies investment interacted with satisfaction in influencing voice. High investment size most strongly promoted voice given high satisfaction. It may be that voice is regarded as a difficult and costly action, and that workers engage in voice only when their motivation to improve conditions is especially strong. Also, in studies one and two this interaction was most pronounced for women: Men behaved as predicted, exhibiting a higher tendency to engage in voice as a function of high investment and satisfaction; women voiced when conditions were most supportive of voice (given high investment and high satisfaction) or when they had nothing to lose (given low investment and low satisfaction). This finding is consistent with work on responses to decline in close relationships, where it has been found that women voice in a wider range of settings than do men (Rusbult, Johnson, \& Morrow, 1986). In fact, study three's finding that men engage in higher levels of neglect than do women may in some sense be the mirror image of this result, given that voice and neglect are conceptual opposites.

The prediction that received the weakest support was that concerning the impact of quality of alternatives on neglect. Support for this prediction came from previous absence research, which suggested that neglect may be a substitute for exit, especially when market conditions prevent employees' quitting (Porter \& Steers, 1973; Rosse \& Miller, 1984). This line of reasoning is intuitively compelling, but in light of the present findings we propose the use of a broadened definition of alternatives, one that takes into consideration not just market conditions but all alternative activities that place restrictions on or provide alternatives to a current employment situation. It may also be that quality of alternatives asserts asymmetrical effects. Perhaps having good alternatives encourages an individual to do something; good alternatives may provide the motivation and power to "shape up or ship out." However, the reverse may not necessarily be true-people with poor-quality alternatives are not necessarily driven toward greater and greater passivity.

Study three revealed that over the course of an unfolding period of dissatisfaction, employees showed increased intentions to engage in exit, voice, and neglect and evidenced reduced loyalty. This finding suggests that there may be interesting temporal aspects of responding to job dissatisfaction. It is possible that there are natural progressions in response mode, such that loyalty is more probable as an initial response than it is following another reaction, like voice. Indeed, this may be particularly true if dissatisfaction persists or conditions decline further. It is also possible that loyalty and the other responses are mutually exclusive, so that engaging in exit or voice or neglect implies that an individual is not likely to be engaging in loyalty. However, such a speculation is clearly tentative at present and remains to be explored in future work. 
Several limitations of the present work should be noted. First, only study two examined actual employees in real organizational settings. Future investigators will need to assess the validity of the present model across varied employment settings. Second, none of the three studies measured actual behavior. Study three obtained somewhat behavioral measures of response intentions, but future research will need to examine the relations among model variables and actual measures of exit, voice, loyalty, and neglect such as absence behaviors and grievance filing. Third, with the exception of study three, the present work was primarily static. In future research it will be important to explore dynamic aspects of responding to job dissatisfaction, including the processes by which employees move from one mode of response to another, probable combinations of responses, and the intensification of responses over the course of an extended period of declining satisfaction. Fourth, the present model does not include the impact of individual-level characteristics on response tendencies. Previous research has shown that needs, stable attitudes, traits, and other enduring dispositions influence important organizational behaviors such as quitting, attendance, and performance (Spector, 1982; Steers \& Braunstein, 1976). A fifth point is that broad organizational characteristics such as size and culture may serve as moderators of the causal relationships examined in the present work. For example, our findings regarding the interaction of satisfaction and investment in influencing voice may be illuminated by Freeman and Medoff's (1984) work on industrial relations, suggesting that institutional factors may enhance felt efficacy and resultant voice tendencies. And sixth, although the present work may serve as the basis for a theory of employee retention, the precise means by which practitioners should modify organizational policies so as to maximize desirable employee behaviors remain to be carefully explicated. Detailed research on individual responses and on specific organizational programs and policies may enhance our ability to predict the effects of innovative personnel and management actions. For example, do pay milestones and golden handcuffs-policies designed to discourage exitalso inhibit destructive neglect?

Several strengths of the present work are also noteworthy. First, the consistency of our findings across three studies with quite varied research strategies reveals that the current findings are not method-specific. Second, by employing a variety of measurement techniques, we demonstrated that the theory's predictions are valid for both self-descriptions and behavioral tendencies and that the predictions are valid for both reactions to particular work situations and more general behavioral tendencies. Third, by exploring relationships among predictors and criteria that were fairly broad, heterogeneous, and abstractly defined, we uncovered some general principles about behavior in organizations, thus integrating findings from disparate studies that have explored rather specific functional relationships.

The present approach extends our theoretical understanding of employee responses to job dissatisfaction in several important respects. First, it is 
noteworthy that the present model identifies multiple dimensions that differentiate among the various responses to decline and emphasizes the diversity of factors that enter into the prediction of response tendencies. This approach suggests that although progression theories (Beehr \& Gupta, 1978) may capture some important features of response patterns, the various reactions to job dissatisfaction do not simply unroll in increasing intensity. Instead, critical features of an employee's unique employment situation are clearly important influences on the four types of response. Second, in the current model employees' attempts to change their organization are viewed as constructive responses to dissatisfaction, as recuperative mechanisms, and (at least in part) as attempts to protect investments made over the course of employment. Responses such as grievance filing have previously been accounted for primarily by reference to employee dissatisfaction and the presence of unions (Dalton \& Todor, 1982). Third, the present approach views employees as sensible, somewhat thoughtful, and frequently planful; individuals are characterized as active controllers of events and outcomes in a work setting, responding in predictable ways to current situational factors. In contrast, in some models there has been greater emphasis on irrational cognitions, emotions, or unconscious conditioning. For example, Mowday, Porter, and Steers (1982) emphasized the power of affective forces in predicting employees' efforts to change work situations, and proponents of adaptation models (Rosse \& Hulin, 1985; Rosse \& Miller, 1984) have assumed that conditioning, role models, and social norms are important influences on responses.

\section{CONCLUSIONS}

The current work contributes to the understanding of behavior in organizations by outlining and empirically testing a comprehensive yet parsimonious model of responses to job dissatisfaction. That predictions advanced in our exchange model of exit, voice, loyalty, and neglect responses were supported across a diversity of measurement techniques, research settings, and participant populations provides a high degree of confidence in the validity of the present approach. Ultimately, the primary function of the exit, voice, loyalty, and neglect model may be an integrative one: to provide a broad model of the essential categories of response to dissatisfaction and the essential causes of each form of response. The model may also serve as a common framework-or general theory -into which researchers may incorporate new predictors and additional responses to dissatisfaction. Finally, the present work suggests that the general exchange theory orientation may be a fruitful approach in accounting for employee responses to decline in job satisfaction. 


\section{REFERENCES}

Adler, S., \& Golan, J. 1981. Lateness as withdrawal behavior. Journal of Applied Psychology, 66: 544-554.

Allen, R. E., \& Keaveny, T. J. 1985. Factors differentiating grievants and nongrievants. Human Relations, 38: 519-534.

Aranya, N., Kushnir, T., \& Valency, A. 1986. Organizational commitment in a male dominated profession. Human Relations, 39: 433-448.

Arkes, H. R., \& Blumer, C. 1985. The psychology of sunk cost. Organizational Behavior and Human Decision Processes, 35: 124-140.

Bateman, T. S., \& Organ, D. W. 1983. Job satisfaction and the good soldier: The relationship between affect and employee "citizenship." Academy of Management Journal, 26: 587595.

Becker, H. S. 1960. Notes on the concept of commitment. American Journal of Sociology, 66: $32-40$.

Beehr, T. A., \& Gupta, N. 1978. A note on the structure of employee withdrawal. Organizational Behavior and Human Performance, 21: 73-79.

Behrend, H. 1953. Absence and labor turnover in a changing economic climate. Occupational Psychology, 27: 69-79.

Blau, G. J. 1985. Relationship of extrinsic, intrinsic, and demographic predictors to various types of withdrawal behaviors. Journal of Applied Psychology, 70: 442-450.

Blau, P. M. 1964. Exchange and power in social life. New York: Wiley.

Buchanan, B. II. 1974. Building organizational commitment: The socialization of managers in work organizations. Administrative Science Quarterly, 19: 533-546.

Calder, B. J. 1977. An attribution theory of leadership. In B. M. Staw \& G. R. Salancik (Eds.), New directions in organizational behavior: 179-204. Chicago: St. Clair.

Campion, M. A., \& Mitchell, M. M. 1986. Management turnover: Experiential differences between former and current managers. Personnel Psychology, 39: 57-69.

Clegg, C. W. 1983. The psychology of employee lateness, absence, and turnover. Journal of Applied Psychology, 68: 88-101.

Cohen, J., \& Cohen, P. 1975. Applied multiple regression/correlation analysis for the behavioral sciences. Hillsdale, N.J.: Lawrence Erlbaum Associates.

Cook, T. D., \& Campbell, D. T. 1979. Quasi-experimentation: Design and analysis issues for field settings. Boston: Houghton-Mifflin.

Cotton, J. L., \& Tuttle, J. M. 1986. Employee turnover: A meta-analysis and review of implications for research. Academy of Management Review, 11: 55-70.

Crowther, J. 1957. Absence and turnover in the divisions of one company: 1950-1955. Occupational Psychology, 31: 256-270.

Dalessio, A., Silverman, W. H., \& Schuck, J. R. 1986. Paths to turnover: A re-analysis and review of existing data on the Mobley, Horner, and Hollingsworth model. Human Relations, 39: 245-263.

Dalton, D. R., \& Todor, W. D. 1982. Antecedents of grievance-filing behavior: Attitude/behavior consistency and the union steward. Academy of Management Journal, 25: 158-169.

Dillman, D. A. 1978. Mail and telephone surveys: The total design method. New York: Wiley.

Dreher, G. F., \& Dougherty, T. W. 1980. Turnover and competition for expected job openings: An exploratory analysis. Academy of Management Journal, 23: 766-772. 
Farrell, D. 1983. Exit, voice, loyalty, and neglect as responses to job dissatisfaction: A multidimensional scaling study. Academy of Management Journal, 26: 596-607.

Farrell, D., \& Robb, D. L. 1980. Lateness to work: $A$ study of withdrawal from work. Paper presented at the annual meeting of the Academy of Management, Detroit.

Farrell, D., \& Rusbult, C. E. 1981. Exchange variables as predictors of job satisfaction, job commitment, and turnover: The effects of rewards, costs, alternatives, and investments. Organizational Behavior and Human Performance, 28: 78-95.

Farrell, D., \& Rusbult, C. E. 1986. Measurement of responses to job dissatisfaction: Exit, voice, loyalty, and neglect. Unpublished manuscript, Western Michigan University.

Ferris, G. R. 1985. Role of leadership in the employee withdrawal process: A constructive replication. Journal of Applied Psychology, 70: 777-781.

Ferris, K. R., \& Aranya, N. 1983. A comparison of two organizational commitment scales. Personnel Psychology, 36: 87-97.

Fleishman, E. A., \& Harris, E. F. 1962. Patterns of leadership behavior related to employee grievances and turnover. Personnel Psychology, 15: 43-56.

Freeman, R. B., \& Medoff, J. L. 1984. What do unions do? New York: Basic Books.

Gaudet, F. J. 1963. Solving the problems of employee absence. New York: American Management Association.

Guzzo, R. A., Jette, R. D., \& Katzell, R. A. 1985. The effects of psychologically based intervention programs on worker productivity: A meta-analysis. Personnel Psychology, 38: 275-291.

Hill, J. M. M., \& Trist, E. L. 1955. Changes in accidents and other absences with length of service. Human Relations, 8: 121-152.

Hirschman, A. O. 1970. Exit, voice, and loyalty: Responses to decline in firms, organizations, and states. Cambridge, Mass.: Harvard University Press.

Hom, P. W., Griffeth, R. W., \& Sellaro, C. L. 1984. The validity of Mobley's (1977) model of employee turnover. Organizational Behavior and Human Performance, 34: 141-174.

Homans, G. C. 1961. Social behavior: Its elementary forms. New York: Harcourt, Brace, \& World.

Hulin, C. L., \& Smith, P. C. 1965. A linear model of job satisfaction. Journal of Applied Psychology, 49: 209-216.

Jackofsky, E. F. 1984. Turnover and job performance: An integrated process model. Academy of Management Review, 9: 74-83.

Jackofsky, E. F., \& Peters, L. H. 1983. The hypothesized effects of ability in the turnover process. Academy of Management Review, 8: 46-49.

Keller, R. T. 1984. The role of performance and absenteeism in the prediction of turnover. Academy of Management Journal, 27: 176-183.

Kelly, H. H., \& Thibaut, J. W. 1978. Interpersonal relations: $A$ theory of interdependence. New York: Wiley.

Koch, J. L., \& Steers, R. M. 1978. Job attachment, satisfaction, and turnover among public sector employees. Journal of Vocational Behavior, 12: 119-128.

Lammers, C. J. 1969. Strikes and mutinies: A comparative study of organizational conflicts between rulers and ruled. Administrative Science Quarterly, 14: 558-572.

Larson, E. W., \& Fukami, C. V. 1985. Employee absenteeism: The role of ease of movement. Academy of Management Journal, 28: 464-471. 
Locke, E. A. 1969. What is job satisfaction? Organizational Behavior and Human Performance, 4: 309-336.

March, J. G., \& Simon, H. A. 1958. Organizations. New York: Wiley.

McLaughlin, G. W., \& Butler, R. P. 1974. Use of weighting and data on alternative careers to predict retention and commitment: Journal of Applied Psychology, 59: 87-89.

Meyer, J. P., \& Allen, N. J. 1984: Testing the "side-bet theory" of organizational commitment: Some methodological considerations. Journal of Applied Psychology, 69: 372-378.

Miceli, M. P., \& Near, J. P. 1984. The relationships among beliefs, organizational position, and whistle-blowing status: A discriminant analysis: Academy of Management Journal, 27: 687-705.

Milburn, T. W., Schuler, R. S., \& Watman, K. H. 1983: Organizational crisis, part II: Strategies and responses. Human Relations, 36: 1161-1180.

Mowday, R. T., Koberg, C. S., \& McArthur, A. W. 1984. The psychology of the withdrawal process: A cross-validation test of Mobley's intermediate linkages model of turnover in two samples. Academy of Management Journal, 27: 79-94.

Mowday, R. T., Porter, L. W., \& Steers, R. M. 1982. Employee-organization linkages: The psychology of commitment, absenteeism, and turnover. New York: Academic Press.

Muchinsky, P. M. 1977. Employee absenteeism: A review of the literature: Journal of Vocational Behavior, 10: 316-340.

Muchinsky, P. M., \& Maassarani, M. A. 1980. Work environment effects on public sector grievances. Personnel Psychology, 33: 403-414.

O'Connor, E. J., Peters, L. H., Pooyan, A., Weekley, J., Frank, B., \& Erenkrantz, B. 1984. Situational constraint effects on performance, affective reactions, and turnover: A field replication and extension: Journal of Applied Psychology, 69: 663-672.

Owens, A. C. 1966. Sick leave among railwaymen threatened by redundancy: A pilot study. Occupational Psychology, 40: 43-52.

Pascale, R. T. 1978. Personnel practices and employee attitudes: A study of Japanese- and American-managed firms in the United States. Human Relations, 31: 597-615.

Petty, M. M., \& Bruning, N. S. 1980: Relationships between employees' attitudes and error rates in public welfare programs. Academy of Management Journal, 23: 546-551.

Pfeffer, J., \& Lawler, J. 1980. Effects of job alternatives, extrinsic rewards, and behavioral commitment on attitude toward the organization: A field test of the insufficient justification paradigm. Administrative Science Quarterly, 25: 38-56.

Porter, L. W., \& Steers, R. M. 1973. Organizational, work, and personal factors in employee turnover and absenteeism. Psychological Bulletin, 80: 151-176.

Price, J. L., \& Mueller, C. W. 1981. A causal model of turnover for nurses. Academy of Management Journal, 24: 543-565.

Price, J., Dewire, J., Nowack, J., Schenkel, K., \& Ronan, W. 1976. Three studies of grievance. Personnel Journal, 55 (1): 33-37.

Ritzer, G., \& Trice, H. M. 1969. An empirical study of Howard Becker's side-bet theory. Social Forces, 47: 475-479.

Rosenthal, R. 1983. Meta-analysis: Toward a more cumulative social science. In L. Bickman (Ed.), Applied social psychology annual, vol. 4: 65-93. Beverly Hills, Calif.: Sage Publications.

Rosse, J. G., \& Hulin, C. L. 1985. Adaptation to work: An analysis of employee health, withdrawal, and change. Organizational Behavior and Human Decision Processes, 36: 324-347. 
Rosse, J. G., \& Miller, H. E. 1984. Relationship between absenteeism and other employee behaviors. In P. S. Goodman \& R. S. Atkins (Eds.), Absenteeism: New approaches to understanding, measuring, and managing employee absence: 194-227. San Francisco: Jossey-Bass.

Rubin, J. Z., \& Brocker, J. 1975. Factors affecting entrapment in waiting situations: The Rosencrantz and Guildenstern effect. Joumal of Personality and Social Psychology, 31: 1054-1063.

Rusbult, C. E., \& Farrell, D. 1983. A longitudinal test of the investment model: The impact on job satisfaction, job commitment, and turnover of variations in rewards, costs, alternatives, and investments. Journal of Applied Psychology, 68: 429-438.

Rusbult, C. E., Johnson, D. J., \& Morrow, G. D. 1986. Impact of couple patterns of problem solving on distress and nondistress in dating relationships. Journal of Personality and Social Psychology, 50: 744-753.

Rusbult, C. E., \& Lowery, D. 1985. When bureaucrats get the blues: Responses to dissatisfaction among federal employees. Journal of Applied Social Psychology, 15: 80-103.

Rusbult, C. E., Zembrodt, I. M., \& Gunn, L. K. 1982. Exit, voice, loyalty, and neglect: Responses to dissatisfaction in romantic involvements. Journal of Personality and Social Psychology, 43: 1230-1242.

Schneider, J. 1976. The "greener grass" phenomenon: Differential effects of a work context alternative on organizational participation and withdrawal intentions. Organizational Behavior and Human Performance, 16: 308-333.

Sheridan, J. E. 1985. A catastrophe model of employee withdrawal leading to low job performance, high absenteeism, and job turnover during the first year of employment. Academy of Management Journal, 28: 88-109.

Smith, C. A., Organ, D. W., \& Near, J. P. 1983. Organizational citizenship behavior: Its nature and antecedents. Journal of Applied Psychology, 68: 653-663.

Spector, P. E. 1982. Behavior in organizations as a function of employee's locus of control. Psychological Bulletin, 91: 482-497.

Spencer, D. G. 1986. Employee voice and employee retention. Academy of Management Journal, 29: 488-502.

Staw, B. M. 1984. Organizational behavior: A review and reformation of the field's outcome variables. Annual Review of Psychology, 35: 627-666.

Steel, R. P., \& Ovalle, N. K. II. 1984. A review and meta-analysis of research on the relationship between behavioral intentions and employee turnover. Journal of Applied Psychology, 69: $673-686$.

Steers, R. M., \& Braunstein, D. N. 1976. A behaviorally-based measure of manifest needs in work settings. Journal of Vocational Behavior, 9: 251-266.

Steers, R. M., \& Rhodes, S. R. 1978. Major influences on employee attendance: A process model. Journal of Applied Psychology, 63: 391-407.

Stumpf, S. A., \& Hartman, K. 1984. Individual exploration to organizational committment or withdrawal. Academy of Management Journal, 27: 308-329.

Thibaut, J. W., \& Kelley, H. H. 1959. The social psychology of groups. New York: Wiley.

Todor, W. D. 1980. A movement paradox: Turnover? Transfer? Paper presented at the annual meeting of the Academy of Management, Detroit.

Todor, W. D., \& Dalton, D. R. 1982. The relationship of voluntary internal mobility to job satisfaction, commitment, and intent to stay. Paper presented at the annual meeting of the Academy of Management, New York.

VanZelst, R. H., \& Kerr, W. A. 1953. Workers' attitudes toward merit rating. Personnel Psychology, 6: 159-172. 
Wanous, J. P., Stumpf, S. A., \& Bedrosian, H. 1979. Job survival of new employees. Personnel Psychology, 32: 651-662.

Watson, C. J. 1981. An evaluation of some aspects of the Steers and Rhodes model of employee attendance. Journal of Applied Psychology, 66: 385-389.

Wells, D. L., \& Muchinsky, P. M. 1985. Performance antecedents of voluntary and involuntary managerial turnover. Journal of Applied Psychology, 70: 329-336.

Werbel, J. D., \& Gould, S. 1984. A comparison of the relationship of commitment to turnover in recent hires and tenured employees. Journal of Applied Psychology, 69: 687-690.

Wolpin, J., \& Burke, R. J. 1985. Relationship between absenteeism and turnover: A function of the measures? Personnel Psychology, 38: 57-75.

Youngblood, S. A. 1984. Work, nonwork, and withdrawal. Journal of Applied Psychology, 69: 106-117.

Youngblood, S. A., Mobley, W. H., \& Meglino, B. M. 1983. A longitudinal analysis of the turnover process. Journal of Applied Psychology, 68: 507-516.

Zald, M. N., \& Berger, M. 1978. Social movements in organizations: Coup d'etat, insurgency, and mass movements. American Journal of Sociology, 83: 823-861.

\section{APPENDIX A}

\section{Research Materials and Questionnaire Items, Study One}

\section{Simulation Essays ${ }^{\mathrm{\theta}}$}

Please attempt to place yourself in the position of $\mathrm{X}$, the major character in the following essay. Try to imagine that person's feelings and attitudes as vividly as you can, considering what it would be like to be in that situation. You may need to read the essay a couple of times before you are completely familiar with the details of the situation. Then complete the attached questionnaire, indicating how you would react if you were in that situation.

Imagine that you are X. You are working for a good company that pays you a high salary, and your job involves work that you find to be really enjoyable. Thus, you've felt extremely satisfied with your job. You've held this position for a relatively long period of time; you've worked there for two years. Thus, you've invested a lot of time and energy in your job. Recently you were offered a job by another company that you find to be very attractivo-the pay is good and you believe your work would be very challenging and satisfying.

Activities at the office where you work had been proceeding smoothly, but in the past week a problem developed. One day this week your immediate supervisor assigned you a report to complete, told you that the project was your primary responsibility, and said you could organize the sections of the report in whatever way you felt was best. Later in the day the office manager (your supervisor's supervisor) stopped by your desk, picked up and read your work, and gave you a long list of instructions regarding how to change your work, including changing the organization of your report. You didn't feel that the office manager's advice was very good, but worried about whether you should do what the manager suggested or complete the report the way you had originally planned. You felt torn between the two courses of action, and felt unhappy about the problem with which you were faced.

Remember, you've worked for this company for a long period of time, you find your job to be extremely satisfying, and you've recently been offered an alternative job that is very attractive to you. How is $X$ going to react to the situation? Answer the following questions as you would if you were $X$. Record a response for each item using the following scale:

\begin{tabular}{|c|c|c|c|c|c|c|c|c|c|c|}
\hline $\begin{array}{l}\text { Definitely } \\
\text { Would Not React } \\
\text { In This Way }\end{array}$ & 1 & 2 & 3 & 4 & 5 & 6 & 7 & 8 & 9 & $\begin{array}{l}\text { Definitely } \\
\text { Would React } \\
\text { In This Way }\end{array}$ \\
\hline
\end{tabular}




\section{Questionnaire Items ${ }^{b}$}

Prior satisfaction, manipulation checks

Before the problem emerged, how happy had you been with your job?

Before the problem emerged, to what extent had you been satisfied with your job?

Investment size, manipulation checks

Before the problem emerged, for how long had you been working ac your job?

Before the problem, how much time and energy had you invested in your job?

\section{Quality of alternatives, manipulation checks}

How attractive is your alternative job offer? offer?

To what extent do you think you would be satisfied if you were to accept your alternative

\section{Exit, dependent measures}

I would think about quitting my job.

I would give notice that I intended to quit.

I would accept my alternative job offer.

I would quit my current job.

\section{Voice, dependent measures}

I would go to my immediate supervisor to discuss the problem.

I would ask my co-workers for advice about what to do.

I would talk to the office manager about how I felt about the situation. the office.

I would try to solve the problem by suggesting changes in the way work was supervised in

\section{Loyalty, dependent measures}

I would hang in there and wait for the problem to go away.

I would stick with my job through good times and bad times.

I would think that my job was probably as good as most.

I would patiently wait for the problem to disappear.

\section{Neglect dependent measures}

I would lose motivation to do my job as well as I might otherwise.

I would show up late because I wasn't in the mood for work.

I would call in sick occasionally because I didn't feel like working.

I would put less effort into my job.

I would take a lot of breaks or not work as hard.

${ }^{a}$ Italicized portions of essays are the sections that differed across conditions. There were eight versions of the essay, representing a full $2 \times 2 \times 2$ factorial design.

b All items for manipulation checks were 9-point bipolar scales. The items for exit, voice, loyalty, and neglect were anchored with $1=$ definitely would not react in this way, $9=$ definitely would react in this way; these items were randomly ordered.

\section{APPENDIX B}

\section{Questionnaire Items, Study Two a}

\section{Demographic Information Items}

The demographic information items measured age, gender, race, marital status, highest year of schooling completed, job title, and personal income. 


\section{Independent Variable Items}

\section{Satisfaction, independent variable measures}

Concrete measures: The concrete measures of job satisfaction assessed feelings regarding pay, co-workers, supervision, chances for advancement, type of work, job security, and working conditions (not very satisfied, moderately satisfied, or very satisfied).

Global measures: If you had to decide all over again whether to take the job you now have, what would you decide? If a friend asked if he/she should apply for a job like yours with your employer, what would you recommend? How does this job compare to your ideal job? How does your job measure up to the sort of job you wanted when you took it? All things considered, how satisfied are you with your current job?

\section{Investment size, independent variable measures}

Concrete measures: The concrete measures of investment size concerned the degree to which each of several objects/persons/events would be less valuable or lost if the respondent were to quit the job: friends at work, pleasant community, job security, retirement money, a job he/she felt good at, status, good school/church/doctor/etc. (give up little, give up some, or give up much). Additional concrete items were 5-point bipolar scales that measured specific job training, transferable education and training, apprehension of moving, duration to familiarity with work setting, community ties, and job and company tenure (for each, number of years and months).

Global measures: Generally speaking, how much have you invested in this job le.g., time, education and training, personal identity, effort, sacrifices)? Generally speaking, to what extent are there things uniquely associated with this job that you would lose if you were to leave (e.g., retirement money, job security, pleasant community, recreational activities, friends at work, status)? Generally, how much would your life be disrupted if you left this job? All things considered, how much have you "put into" this job?

\section{Quality of alternatives, independent variable measures}

Concrete measures: The concrete measures of quality of alternatives assessed respondents' judged likelihood of getting a job as good as the current one but with better pay, nicer coworkers, more satisfactory supervision, more chances for advancement, more interesting work, better working conditions, more job security, and more meaningful work. Additional concrete items were 5-point bipolar scales that measured number of job offers in the last six months (none, one, or more than one), number of workers in the geographical area with similar training and skills, value of respondent's present job skills five years hence, favorability of job prospects given the current economy, estimated duration to find another satisfactory job, and possession of sufficient funds to tide respondent over during search for an alternative job.

Global measures: If you left this job, would your next job probably be better or worse than the job you have now? How hard would it be for you to find a job with another employer with approximately the same income and benefits you have now? How confident are you that you would find a satisfactory job if you were to quit this job? All things considered, how do your alternatives compare to your current job?

\section{Dependent Variable Items}

\section{Exit, dependent measures}

I have recently spent some time looking for another job.

During the next year I will probably look for a new job outside this company.

When working conditions here decline I think a lot about quitting.

I often think about quitting.

\section{Voice, dependent measures}

When I think of an idea that will benefit my company I make a determined effort to implement it.

I have at least once contacted an outside agency (e.g., union) to get help in changing working conditions here. 
I sometimes discuss problems at work with my employer. whistle."

When things are seriously wrong and the company won't act, I am willing to "blow the

I have made several attempts to change working conditions here.

\section{Loyalty, dependent measures}

I generally say good things about my company even when other people criticize it.

Employees shouldn't criticize this company. work.

I've found that patience is a virtue at my company-time seems to solve most problems at

I sometimes wear clothing (hat, jacket, pin, etc.) that bears the company's symbol or insignia (or I would do so if my company had such clothing).

The people in charge of this company generally know what they're doing.

Neglect, dependent measures

Sometimes when I don't feel like working I will work slowly or make errors.

I try to keep out of sight of my supervisor so I can talk to co-workers, take breaks, or do other personal business (not work).

Now and then there are workdays where I just don't put much effort into my work.

Sometimes when I just don't feel like working I will call in sick.

I care very little about what happens to this company as long as I get a paycheck.

Now and then I arrive at work late just because I really am not in the mood for work that day.

${ }^{a}$ All items were 5-point bipolar scales. The items for exit, voice, loyalty, and neglect were anchored with 1 = definitely would not react in this way, 5 = definitely would react in this way; these items were randomly ordered.

\section{APPENDIX C}

\section{Questionnaire Items, Study Three a}

\section{Independent Variables, Manipulation Checks}

\section{Job-satisfaction measures}

How adequate is your pay as compensation for this job?

Is that level of pay satisfactory to you?

How does that level of pay compare to the average pay for other newsroom tasks?

\section{Investment-size measures}

Was your training specific to the task you were assigned?

Did this training help you perform better at your job?

How helpful would that training be if you were to switch to an alternative job?

\section{Quality-of-alternatives measures}

How adequate is the pay as compensation for work on the alternative task?

Would the level of pay for the alternative task be satisfactory to you?

How does that level of pay compare to the average pay for other newsroom tasks?

\section{Decline-in-satisfaction measures}

How difficult was your work during this session?

How well do you think you performed during this session?

To what extent was work during this session satisfying?

\section{Dependent variables, self-report items}

\section{Exit, dependent measures}

I am seriously considering quitting my assigned job for my alternative job.

I am thinking about transferring from my assigned job to my alternative job. 
I want to switch to my alternative newsroom job.

I want to trade my assigned job for my alternative job.

I will tell the management that $I$ want to adopt my alternative job.

\section{Voice, dependent measures}

I have an idea that I think will improve the feedback system, and I will make a serious effort to implement it.

I want to discuss the evaluation/feedback system with my supervisor. conditions.

I want to talk things over with my co-workers to get their help in changing working

I want to suggest changes in the procedures by which work is assigned or evaluated.

I want to change the way in which things are done in the newsroom. feedback.

I want to talk to my supervisor about the difficulty of the job and/or the nature of the

I will work harder-this job is difficult, but "do-able."

\section{Loyalty, dependent measures}

I will say good things about my assigned job even when other people criticize it.

I will patiently wait for the evaluation system to improve.

I think that my job is probably as good as most.

I will quietly stick with my assigned job through good and bad times.

There are some things about the assigned task that bother me, but every job has some negative features.

I will speak highly of the job to friends.

\section{Neglect, dependent measures}

I have lost motivation for my assigned job; I might work more slowly or make more errors.

I might call in sick occasionally because I don't feel like working on my job.

I feel like putting less effort into my assigned job.

I will begin to take a lot of breaks and do less work.

I might begin to show up late because I am not in the mood for working at my job.

I have quit caring about my job and will allow conditions to get worse and worse.

I feel like saying something rude to my supervisor.

a All items were 7-point bipolar scales, with $1=$ not all and $7=$ completely or $1=$ definitely would not react in this way, $7=$ definitely would react in this way. On the response-to-jobdissatisfaction self-report items, subjects were asked to assume that their experience during the previous session represented experiences during a one-month period. The exit, voice, loyalty, and neglect items were randomly ordered.

Caryl Rusbult received her Ph.D. degree in psychology from the University of North Carolina at Chapel Hill. She was an associate professor at the University of Kentucky until 1986, at which time she returned to the Department of Psychology at the University of North Carolina at Chapel Hill as an associate professor. In addition to her research on retention behaviors, her research interests include commitment in close relationsips and employee compensation.

Dan Farrell received his $\mathrm{Ph} . \mathrm{D}$ degree in organizational sociology from the University of Iowa. He is currently an associate professor of management at Western Michigan University. In addition to his research on retention behaviors, his interests include political behavior in organizations, especially whistle-blowing.

Glen Rogers received his Ph.D. degree in psychology from the University of Kentucky. $\mathrm{He}$ is currently a research associate in the Office of Research and Evaluation at Alverno College in Milwaukee, Wisconsin.

Arch Mainous is currently a Ph.D. candidate in the Department of Sociology at the University of Texas at Austin. 
Copyright of Academy of Management Journal is the property of Academy of Management and its content may not be copied or emailed to multiple sites or posted to a listserv without the copyright holder's express written permission. However, users may print, download, or email articles for individual use. 